\title{
Implicit Taxation of Pakistan's Agriculture: An Analysis of the Commodity and Input Prices
}

\author{
M. Ghaffar Chaudirgy and Nigilat Naiefed Kayani
}

The purpose of the present paper has been to quantify and discuss the implications of implicit taxes in Pakistan's agriculture. The methodology of the paper consisted of defining the import and export parity prices of major agricultural commodities grown in Pakistan, by comparing them with domestic procurement prices. Although the analysis covered only four commodities, implicit tax rates in some of the years from 1970-71 to 1989-90 were as high as 75 percent for certain commodities. It was only in the case of IRRI rice and sugarcane that domestic prices were above the world levels in some years of the period under consideration. When shown as a percentage of the value-added by agriculture, the taxes on these four commodities, net of the total budgetary subsidies on agricultural inputs, varied from 1.9 percent to 14.9 percent. These tax rates in agriculture compared favourably with the overall tax rates in Pakistan's economy for most of the years. Judged in the light of the relative taxable capacities of agriculture and Pakistan's economy as a whole, implicit taxes were much higher in agriculture than in the other sectors of the economy.

\section{INTRODUCTION}

Capital formation, the key to economic development, is difficult in the less developed countries, including Pakistan, because development resources are scarce there. Although the paucity of investible funds could be alleviated by foreign aid, it is neither a dependable source nor does it contribute to capital formation as it entails a reverse flow of resources for repayment and servicing of debt. Among the domestic revenue sources, taxation is unexcelled in manoeuvrability and effectiveness as a means of control of the economy [Economic Commission for Asia and the Far East (1966)]. Besides, taxation may also be helpful in inculcating the spirit of self-reliance, promoting privatc incentives, and narrowing income gaps.

As a major sector of Pakistan's economy, agriculture is correctly expected to make a significant contribution to the development finance in the country. However, opinion regarding the agriculture's actual role in this respect is sharply

M. Ghaffar Chaudhry is Joint Director and Nighat Naheed Kayani is Staff Economist at the Pakistan Institute of Development Economics, Islamabad.

Authors' Note: We are decply indebted to Dr Gary Ender of the USAID (Islamabad) for many fruitful discussions as well as supply of the latest available literature on the subject. We also acknowledge helpful comments made by an anonymous referee. 
divided. On the one side of the spectrum are studies that support the common belief that agriculture has contributed little to the government exchequer by way of taxes, and that it has enjoyed huge subsidies on agricultural inputs [Hamid (1970); Khan (1985) and Qureshi (1987)]. On the other side of the spectrum are studies which postulate that agriculture was overtaxed, compared with other sectors of the economy, even after the adjustment of subsidies on agricultural inputs [Chaudhry (1973); Government of Pakistan (1987, 1988)]. The underlying reason for the diametrically ópposite conclusions of the two sets of studies lies in the inclusion or exclusion of certain kinds of taxes in the analysis. While the studies of the latter category had a somewhat complete coverage of the various taxes paid by agriculture, the conclusions of the studies by Hamid (1970) and Khan (1985) were based on direct taxes on agriculture levied by the provincial governments, completely ignoring the direct and indirect taxes of local governments, indirect taxes of provincial and federal governments, and the taxes paid by agriculture in the form of an overvalued exchange rate and the low prices of agricultural commodities. In his analysis of the incidence of indirect taxes of the federal government, Qureshi (1987) has failed to include the local government taxes as well as the taxes couched in the low prices of agricultural commodities. In the light of the recent rapid growth of local finance, growing government intervention in the agricultural sector, and a movement towards greater reliance on indirect taxes, Qureshi's conclusion that agriculture was undertaxed appears to be the direct result of his having excluded some of these taxes from his calculations.

Part of the reason for the exclusion of certain kinds of taxes springs from the complexity of the agricultural tax system and the attendant problems of quantification of taxes paid by agriculture. This quantification must be based on inclusion of the direct taxes paid by farmers, including the local finance, the contribution of agriculture to the indirect taxes calculated from a proper incidence-analysis, the resource transfers from agriculture due to exchange-rate policies, and the tax burden of agriculture implicit in the prices of agricultural commodities and inputs. Since a comprehensive quantification of all aspects of agricultural taxation is an uphill task, and cannot be undertaken in a short paper like the present one, we concentrate on the analysis of the prices of agricultural commodities and inputs for a quantification of the implicit taxes and subsidies in Pakistan's agriculture from 1970-71 to 1989-90. However, our analysis of prices, due to the limitations of the data, is restricted to wheat, rice, cotton, and sugarcane, according to the following outline. The paper is divided into five sections including the present introductory section. The discussion in Section 2 pertains to the various methodologies employed for the calculation of implicit taxes as well as the approach used in this study. Section 3 presents the results of our analysis, as well as estimates of the taxes implicit in the commodity prices and the subsidies on 
agricultural inputs. Agriculture's tax burden (taxes as a percentage of the valueadded by agriculture), both gross and net of subsidies, is also reported and compared with the overall tax burden in Pakistan. Section 4 highlights the policy implications of the discussion in Section 3 for the purposes of agricultural growth, income distribution, agricultural tax policy, and farm credit. The final section presents the summary and the conclusions of the study.

\section{APPROACHING THE PROBLEM}

Three aggregate measures of support have commonly been used in the literature to quantify the magnitude of taxes and subsidies - arising out of government intervention of one kind or another in the agricultural commodity markets and the resulting price distortions. They include nominal protection coefficients, effective protection coefficients, and producer subsidy equivalents [Wainio et al. (1988); Scandizzo and Bruce (1990)]. The nominal protection coefficient is theoretically the simplest measure and among those earliest used, which is generally expressed as a ratio of the domestic prices to world prices. The effective protection coefficient is also a ratio and depicts the relationship between the values added at domestic producer prices and those at international or world prices. The producer subsidy equivalent is often expressed in terms of the total value of subsidy as a percentage of adjusted producer income (and receipts plus net direct payments). Put slightly differently, the producer subsidy equivalents represent the comparisons of import or export parity prices with domestic prices for the calculation of taxes and subsidies, which are then expressed as a percentage of adjusted producer incomes [Ender (1989)].

It will be noted from the foregoing that these three measures are not totally different from each other and may be regarded as alternative measures. They all have a common methodology. Each makes use of the domestic and world prices as a yardstick of taxes and subsidies, and each relics on many of the same calculation procedures. Nonetheless, each tells a somewhat different story because of the different built-in coverage of various government programmes. For example, both effective protection coefficients and producer subsidy equivalents provide a built-in coverage of input subsidies but the nominal protection coefficients lack this property. Similarly, marketing subsidies, long-term production programmes, direct-income supports and exchange-rate controls are an integral part of the calculation of producer subsidy equivalents but are not accounted for in the other two approaches.

To the extent that the three aggregate measures of the Government support to agriculture are only alternative measures, the analysis of this paper is based on nominal protection coefficients. The choice of the measure has been made not 
only because of its theoretical simplicity but also because of many factors and limitations. Direct-income support programmes are uncommon in Pakistan; and exchange rate controls are outside the scope of this paper. There was, therefore, no need to indulge in sophisticated concepts of effective protection coefficients and producer subsidy equivalents. The transport subsidies involving costs associated with transportation, marketing, and storage could be built into the calculation of nominal protection coefficients and brought closer to the approach of producer subsidy equivalents. This could be done by defining the concept as a ratio of domestic prices to import or export parity prices [Appleyard (1986)]. Input subsidies could be treated separately and deducted from gross taxes for an analysis of the taxes net of subsidies. The separate treatment of input subsidies seems to be inevitable owing to non-availability of the time-scries data on the world prices of purchased agricultural inputs [Wainio et al. (1988)]. The absence of such data precludes the possibility of estimating effective protection coefficients and producer subsidy equivalents.

Although less impinging than the requirements of the other two measures, the data needs of the nominal protection coefficient approach are by no means small. Apart from the price data at the world and domestic levels, the data on production and marketed surpluses are also needed for tax calculations. The calculation of import and export parity prices immediately involves adjustment of c.i.f. import and f.o.b. export prices for transportation, storage, and loading-unloading costs between the farm and the port of destination. Because of the semi-finished form of major exportables and importables in contrast to raw farm products, the use of conversion factors and processing costs becomes inevitable for meaningful comparisons of international and domestic prices at the farm level. The calculation of the taxes net of subsidies requires data on subsidies for major agricultural inputs. While data on production and prices are readily available from published secondary sources, there is a general lack of the time-series data on transportation and storage costs, loading-unloading charges, and the processing costs of the cotton, rice, and sugar mills. Some limited information for a limited period, however, was available on these variables in Appleyard (1986) and Ender (1989). Using this information, we were able to generate the time-series data for the entire 20-year period through multiplication by various price-indices. For example, the value of transportation and storage costs reported in these studies were multiplied by the implicit price deflator for transportation, storage, and the communications sector to arrive at the cost figures for each of the years between 1970-71 and 1989-90. A similar index of electricity and gas was used to update the processing costs. Loading and unloading charges were estimated for each year through multiplication of the given figures by an index of wage rates of unskilled construction workers in Karachi. 


\section{ANALYSIS OF IMPLICIT COMMODITY TAXES AND SUBSIDIES}

We begin our analysis by reporting nominal protection coefficients for the major agricultural commodities grown in Pakistan. It is followed by a discussion of the inter-temporal trends and their implications for commodity tax rates. Attention is then centred on the magnitude of the implicit taxes on agriculture, both gross and net of input subsidies, which are reported in various budgets. These taxes are also shown as a percentage of the value-added by agriculture, if only to compare them with the relative tax burden of the national economy.

\section{Nominal Protection Coefficients}

As should be clear from the preceding section, nominal protection coefficients for the purposes of this study were defined by a ratio between domestic (procurement) prices and the import or export parity prices. This was considered necessary to keep the price effect of the transportation and processing costs as separate from that of the taxes and subsidies. The computational details of estimating the import or export parity prices and, for that matter, of the nominal protection coefficients, are given in Appendix Tables A-1 to A-4. As a summary of these Appendix Tables, Table 1 reports the estimated nominal protection coefficients for various crops from 1970-71 to 1989-90.

While the value of nominal protection coefficients was close to unity in the beginning year of the 1970s, it continued to fall and plummeted to the lowest levels in 1974-75, or a year earlier. Between 1974-75 and 1979-80, domestic farmgate prices of most commodities rose relative to international farmgate prices. Although the nominal protection coefficients for wheat rose consistently over this period, those for colton, rice, and sugarcane fell somewhat after reaching a peak level in 1977-78. The ratios of domestic farmgate prices to international farmgate parity prices for IRRI rice and sugarcane were consistently higher for the years between $1979-80$ and $1984-85$, but fluctuated over the period to settle at a lower level in 1984-85 relative to $1979-80$ in the case of cotton, Basmati rice, and wheat. In the subsequent period of 1984-85 - 1989-90, most of the nominal protection coefficients exhibited a mixed trend over the years but the domestic prices of most commodities were only half of those of international prices in the terminal year of $1989-90$, with the lowest range of 40 percent in the case of Basmati rice and the highest range of 58 percent in the case of sugarcane.

Implicit in the estimated nominal protection coefficients is the rate structure of commodity taxes. While this rate structure varicd with commodities as well as with the time period under consideration, the average tax-rate for a given commodity and for a given period could be estimated by subtracting the nominal 
Table 1

Nominal Protection Coefficients of Various Crops 1970-71 to 1989-90

\begin{tabular}{lccccc}
\hline Years & Cotton & $\begin{array}{c}\text { Rice } \\
\text { (Basmati) }\end{array}$ & $\begin{array}{c}\text { Rice } \\
\text { (IRRI) }\end{array}$ & Sugarcane & Wheat \\
\hline $1970-71$ & 1.03 & 0.96 & 0.78 & 0.50 & 0.94 \\
$1971-72$ & 0.47 & 0.57 & 0.49 & 0.64 & 0.88 \\
$1972-73$ & 0.56 & 0.39 & 0.40 & 0.73 & 0.63 \\
$1973-74$ & 0.41 & 0.30 & 0.20 & 0.45 & 0.48 \\
$1974-75$ & 0.58 & 0.29 & 0.23 & 0.37 & 0.49 \\
$1975-76$ & 0.69 & 0.40 & 0.44 & 0.44 & 0.56 \\
$1976-77$ & 0.54 & 0.59 & 0.71 & 0.76 & 0.56 \\
$1977-78$ & 0.82 & 0.52 & 0.81 & 0.76 & 0.63 \\
$1978-79$ & 0.75 & 0.31 & 0.59 & 0.78 & 0.64 \\
$1979-80$ & 0.70 & 0.34 & 0.58 & 0.47 & 0.70 \\
$1980-81$ & 0.64 & 0.40 & 0.51 & 0.49 & 0.59 \\
$1981-82$ & 0.83 & 0.36 & 0.53 & 0.61 & 0.54 \\
$1982-83$ & 0.72 & 0.39 & 0.88 & 0.87 & 0.60 \\
$1983-84$ & 0.61 & 0.40 & 0.90 & 0.95 & 0.46 \\
$1984-85$ & 0.63 & 0.33 & 0.75 & 1.73 & 0.52 \\
$1985-86$ & 0.78 & 0.30 & 1.13 & 1.19 & 0.65 \\
$1986-87$ & 0.74 & 0.30 & 1.18 & 1.53 & 0.53 \\
$1987-88$ & 0.48 & 0.37 & 0.88 & 1.85 & 0.54 \\
$1988-89$ & 0.50 & 0.38 & 0.61 & 1.43 & 0.54 \\
$1989-90$ & 0.48 & 0.40 & 0.50 & 0.58 & 0.48 \\
\hline
\end{tabular}

Source: Appendix Tables A-1 to A-4.

protection coefficient from unity. It is common sense that the taxes on a commodity will be negative, positive, or zero as the respective values of the estimated coefficient exceed, fall short of, or are equal to unity. On this scale, wheat and rice (Basmati) prices throughout the entire 20-year period were so fixed as to contain an element of taxation. This was also true of seed cotton prices except in 1970-71, when domestic cotton price exceeded the export parity price by a margin of 3 percent. Negative tax rates of 13-18 percent appeared in 1985-86 and 1986-87 for rice (IRRI), and of $19-85$ percent from $1984-85$ to $1988-89$ in the case of sugarcane. Depending on the period under consideration, the positive tax rates were of the order of 17-53 percent for cotton, 4-71 percent for Basmati rice, 10-18 percent for IRRI rice, 5-51 percent for sugarcane, and 6-52 percent for wheat. 
Although the domestic commodity prices witnessed a consistently rising inter-temporal trend, the variation in the rate structure of taxes on various commodities has been the result mainly of fluctuations in the prices of primary commodities in the international market. The rising costs of transportation, processing costs, and a constantly falling value of the Rupee, especially in the Eighties, were the other factors that affected the rate structure of implicit commodity taxes from time to time.

\section{Magnitude of Implicit Taxes in Agriculture}

Although the rate structure of implicit taxes for various commodities gives a fairly good idea of the taxes on agriculture, it still fails to depict the exact magnitude of such taxes. This would be especially true under the simultaneous existence of positive and negative tax rates for various commodities. It is, therefore, essential to quantify total implicit taxes in agriculture. The exercise would also be helpful in studying the impact of these taxes on agriculture net of input subsidies. The quantification of implicit taxes could be accomplished by multiplying the price differences between international and domestic prices by the marketed quantities of various commodities. Since the prices of the cane-based farm products are not fixed by the government, the cane used for this purpose is excluded from our estimates, and the cane crushed by sugar mills is equated to the output marketed by the farm sector. While the detailed results of this exercise are shown in Appendix Tables A-1 to A-4, Table 2 presents total implicit taxes, their relationship with the value-added by agriculture, and the consolidated tax and non-tax receipts of federal and provincial governments as a percentage of the gross national product of Pakistan.

It is clear from Table 2 that implicit taxes by no means involved small amounts of resource transfers from agriculture. Gross implicit taxes were of the order of Rs 0.5 billion in 1970-71, but rose to Rs 28.0 billion in 1989-90. A similar picture emerges in respect of implicit taxes net of subsidies on fertilizers, tubewell installation, pesticides, and seeds.' Although net taxes amounted to Rs 0.9 billion in 1972-73, they stood at Rs 25.9 billion in 1989-90. These figures correspond with annual growth rates of 22.0 percent and 20.6 percent, respectively, for gross and net implicit taxes. It, therefore, seems naive to argue that taxes in agriculture failed to keep pace with the rise in agricultural productivity or, for that matter, in agricultural incomes. Net implicit taxes as a percentage of the

${ }^{1}$ I understand that the use of economic subsidies would have been more appropriate than that of budgetary subsidies. The non-availability of world prices of these inputs, and their cost structure, makes it difficult to offer estimates of economic subsidies on agricultural inputs. 
Table 2

Implicit Taxes and Subsidies in Agriculture, 1970-71 to 1989-90

\begin{tabular}{|c|c|c|c|c|c|c|}
\hline Years & $\begin{array}{l}\text { Implicit } \\
\text { Taxes }\end{array}$ & $\begin{array}{c}\text { Input } \\
\text { Subsidies }\end{array}$ & $\begin{array}{c}\text { Taxes } \\
\text { Net of } \\
\text { Subsidies }\end{array}$ & $\begin{array}{l}\text { Value- } \\
\text { added by } \\
\text { Agricul- } \\
\text { ture at } \\
\text { Current } \\
\text { Factor }\end{array}$ & $\begin{array}{c}\text { Net } \\
\text { Taxes } \\
\text { as Percent } \\
\text { of Value- } \\
\text { added by } \\
\text { Agriculture }\end{array}$ & $\begin{array}{l}\text { Overall } \\
\text { Tax } \\
\text { Rates in } \\
\text { Pakistan }\end{array}$ \\
\hline \multicolumn{7}{|c|}{ Million Rupee } \\
\hline $1970-71$ & 521.85 & - & - & 16,236 & 6 & 12.7 \\
\hline $1971-72$ & $1,280.81$ & - & - & 17,934 & - & 13.56 \\
\hline $1972-73$ & $1,236.14$ & 345 & 891.14 & 21,907 & 4.97 & 12.37 \\
\hline $1973-74$ & $4,532.99$ & 351 & $4,181.99$ & 28,084 & 14.89 & 13.47 \\
\hline $1974-75$ & $5,028.75$ & 454 & $4,574.75$ & 33,533 & 13.64 & 12.80 \\
\hline $1975-76$ & $3,844.38$ & 1,012 & $2,832.38$ & 38,338 & 7.39 & 13.28 \\
\hline $1976-77$ & $3,801.38$ & 914 & $2,887.36$ & 43,968 & 6.57 & 13.28 \\
\hline $1977-78$ & $2,283.11$ & 1,160 & $1,123.11$ & 50,567 & 2.22 & 14.05 \\
\hline $1978-79$ & $3,403.97$ & 1,983 & $1,420.97$ & 54,147 & 2.62 & 14.66 \\
\hline $1979-80$ & $5,458.17$ & 2,723 & $2,735.17$ & 62,164 & 4.40 & 15.25 \\
\hline $1980-81$ & $8,433.92$ & 2,479 & $5,954.92$ & 76,399 & 7.80 & 15.66 \\
\hline $1981-82$ & $9,893.53$ & 1,826 & $8,067.53$ & 92,216 & 8.75 & 14.96 \\
\hline $1982-83$ & $6,427.30$ & 1,980 & $4,447.30$ & 99,380 & 4.48 & 14.67 \\
\hline $1983-84$ & $9,665.40$ & 1,690 & $7,975.40$ & 104,550 & 7.63 & 15.69 \\
\hline $1984-85$ & $6,465.54$ & 1,501 & $4,964.54$ & 121,293 & 4.09 & 14.87 \\
\hline $1985-86$ & $4,917.37$ & 2,424 & $2,493.36$ & 128,801 & 1.94 & 15.27 \\
\hline $1986-87$ & $10,561.42$ & 1,142 & $9,419.42$ & 135,308 & 6.96 & 16.11 \\
\hline $1987-88$ & $12,909.96$ & 2,190 & $10,719.96$ & 156,375 & 6.86 & 16.32 \\
\hline $1988-89$ & $13,751.80$ & 1,400 & $12,351.80$ & 185,498 & 6.66 & 17.46 \\
\hline $1989-90$ & $28,036.31$ & 2,100 & $25,936.41$ & 205,980 & 12.59 & 17.38 \\
\hline
\end{tabular}

Source: Appendix Tables A-1 to A-4 and Govemment of Pakistan (1990).

value-added by agriculture, like the rate structure, varied considerably from time to time, with lower and upper bounds of 1.9 percent and 12.6 percent. These percentages compare with the overall tax rates (total government revenue as a percentage of the GNP in Pakistan) of 12.4 - 17.5 percent over the 20-ycar period under consideration.

The comparison of implicit taxes in agriculture with overall tax rates in Pakistan suggests that, by Pakistani standards, the tax burden in agriculture was 
really heavy during some of the years, if not for the entire period. It needs to be pointed out, however, that even the lowest rates of implicit taxes in agriculture compare favourably with overall tax rates of Pakistan's economy for the following reasons. First, implicit tax rates as reported in Table 2 are nct of resource transfers into agriculture, but the same deductions have not been made from the overall tax rates. Second, we considered only one source of taxes in agriculture against the inclusion of all the revenue sources reflected in the overall tax rates. Finally, and more importantly, agricultural income was one-half to one-third and agriculture's taxable capacity only onc-tenth of those in the non-agricultural sector between 1970-71 and 1989-90 [Qureshi (1989)]. From this perspective, even the lowest implicit tax rates in agriculture would represent over-taxation of agriculture, relative to Pakistan's economy under proportionate progression of tax rates.

Despite the immense resource transfers from agriculture, there is little recognition in Pakistan that agriculture may be over-burdened with taxes. The underlying reason for overlooking this fact has to do with the exclusion of a major part of implicit taxes from government budgets. Only cotton export duties and profits of cotton and rice export corporations are reported in the budgets. But a major proportion of these taxes accrues to consumers as food subsidies and to industrialists in the form of low raw-material prices [Gotsch and Brown (1980)] is generally overlooked. It is this anomaly which results in the misgiving that agriculture makes little contribution to government revenues.

\section{IMPLICATIONS FOR AGRICULTURAL DEVELOPMENT AND POLICY}

There is a general agreement in the literature that resource transfers from agriculture hold the key to rapid transformation and modernization of traditionbound economies of the world. It may be noted, however, that resource mobilization through under-pricing of agricultural commodities is one of the most incfficient ways of accomplishing the lask as it interferes with the comparative advantage theory and a sustainable process of cconomic development in many ways. First, low prices of agricultural commodities under-estimate agriculture's contribution to national economy and result in serious flaws in the planning, management, and allocation of funds to agricultural development. Secondly, under-pricing of agricultural commodities corresponds directly to low-farm incomes, lowfarm profitabilities, and a distortion of private incentives with adverse effects on the growth of agricultural output and the output of the national economy [Bale (1985); Krueger et al. (1988)]. The available estimates of aggregate price clasticity of supply with respect to output [Ali (1990)], coupled with the current levels 
of domestic and international prices, suggests a nearly 30-percent annual loss of agricultural production due to low prices of agricultural commodities. Thirdly, such huge losses of agricultural production cause similar losses in the output of other sectors of the economy, especially in the industrial sector, due to their output's direct dependence on agricultural raw materials for production, and on agricultural incomes for an effective disposal of that production. Fourthly, one of the outcomes of these developments appears in the form of Pakistan's continued dependnence on imports and foreign aid. Fifthly, low domestic production also tends to limit Pakistan's ability to absorb its labour force in productive employment. Finally, while the lack of productive employment opportunities is one of the major sources of income inequalities, the indiscriminate use of the price policy for resource mobilization from agriculture adds a special dimension to the problem. Inter-farm income differences and differences in investment-ability are accentuated by the regressive impact of the price policy on small farms. Although urban incomes tend to be higher than rural incomes, the policy of low agricultural commodity prices would lead to widening of urban-rural income differentials. The same is likely to happen within the urban areas as the industrialists benefit doubly from this policy, first as users of agricultural raw materials and then as consumers of food.

It follows from the above that agricultural price policy in Pakistan has been directly opposed to the goals of economic devclopment, and that it needs to be amended to ensure a more rapid progress, greater cmployment, and better income distribution than have hitherto been achieved. The most efficient way to accomplish this task is to set agricultural commodity prices on a par with import and export parity prices of various agricultural commodities. To dampen the effect of wide fluctuations in international prices of primary commoditics and to ensure stability of prices at home, domestic farm prices should be determined by trend lines so that they are higher than world prices during periods of low international prices, and lower than world prices during periods of high world prices. As the fluctuations around trends would be cancelled out over time, the prices so fixed would be consistent with zero implicit taxes in Pakistan.

It has been noted above that under-pricing of agricultural commodities is one of the highly regressive and incquitable systems of taxing agriculture. It is commonly recommended in Pakistan that the general income-tax system should be extended immediately to agriculture as well. The recommendation is made without any emphasis of the need for repealing implicit taxes in agriculture. Taken at its face value, such a recommendation is likely to make agricultural taxes more oppressive. Since implicit taxes involve huge amounts, an extension of income tax to agriculture, despite its desirability, would accomplish little in promoting progressive tax rates in agriculture. This, however, is not to suggest that income 
tax should not be extended to agriculture, but only that it should be done, if at all, after appropriate changes in agricultural prices.

The removal of implicit taxes will obviate the need for arranging elaborate institutional credit for agriculture. As special arrangements for agricultural credit are associated with huge social costs in terms of institutional fees, establishment costs, and service charges, with a disproportionate accrual of the principal to large farmers, their discontinuation will save billions of rupees each year for investment elsewhere. Although some farmers may still be in need of credit after the withdrawal of special arrangements, they could be productively served by commercial banks at a nominal cost to the society.

\section{SUMMARY AND CONCLUSIONS}

The purpose of the present paper has been to quantify and discuss the implications of implicit taxes in Pakistan's agriculture. The methodology of the paper consisted of defining the import and export parity prices of major agricultural commodities grown in Pakistan, by comparing them with domestic procurement prices. Although the analysis covered only four commodities, implicit tax rates in some of the years from 1970-71 to 1989-90 were as high as 75 percent for certain commodities. It was only in the case of IRRI rice and sugarcane that domestic prices were above the world levels in some years of the period under consideration. When shown as a percentage of the value-added by agriculture, the taxes on these four commodities, net of the total budgetary subsidies on agricultural inputs, varied from 1.9 percent to 14.9 percent. These tax rates in agriculture compared favourably with the overall tax rates in Pakistan's economy for most of the years. Judged in the light of the relative taxable capacities of agriculture and Pakistan's economy as a whole, implicit taxes were much higher in agriculture than in the other sectors of the economy. Although agriculture secms to be overtaxed in this context, the general conclusion that agriculture is undertaxed in Pakistan is mainly based on the exclusion of implicit taxes from the government budgets and major studies done on Pakistan.

The abysmally low agricultural commodity prices and the variation across commodities have tended to impair resource-use efficiency in agriculture, lessen growth and employment, and accentuate the existing income incqualities. As these trends are inconsistent with the desired goals of economic development, the policy of under-pricing of agricultural commodities needs to be abandoned. In the presence of huge implicit taxes, the desired progression in agricultural taxation cannot be introduced with the extension of general income tax to agriculture. Likewise, discontinuation of under-pricing of agricultural commodities is likely to release the huge resources for investment currently tied to institutional credit for agriculture. 
$\frac{\dddot{z}}{8}$

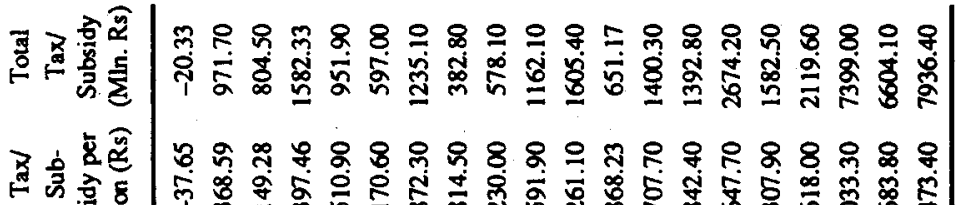
ผ के

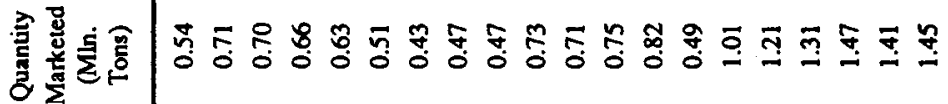

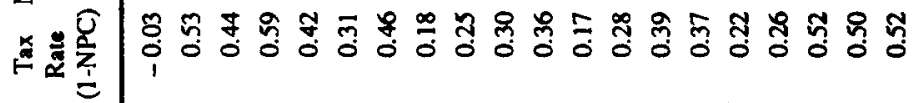

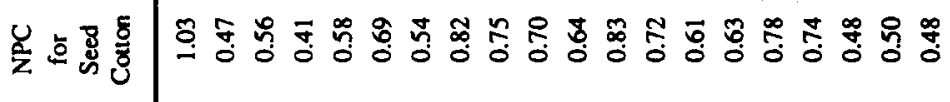

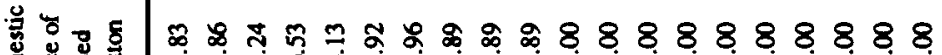

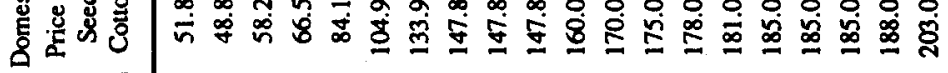

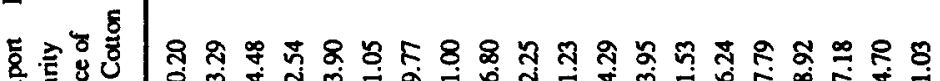

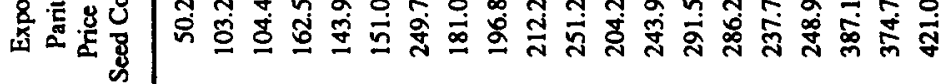

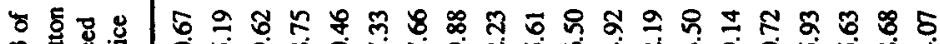

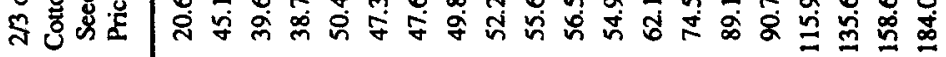
당ㄱำ

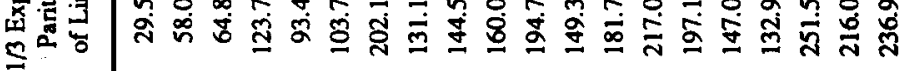
空

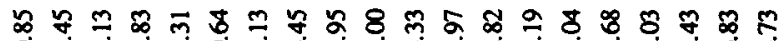
2 . 2

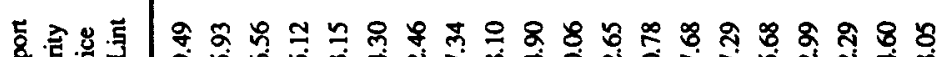

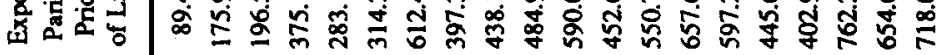
เ

(⿻)

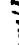

\$ั

$\stackrel{2}{\stackrel{5}{*}}$

ปี

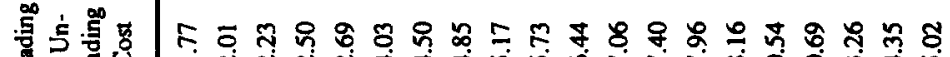

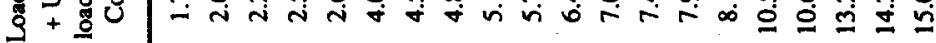

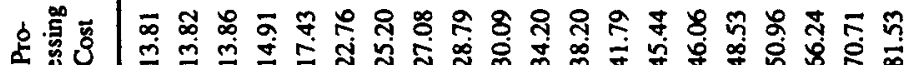

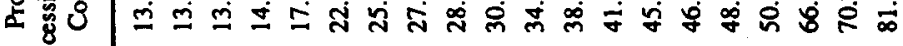

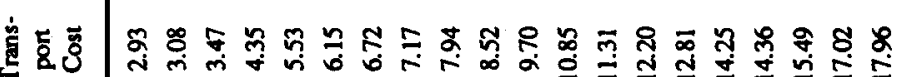
है8

舟若 8 苛

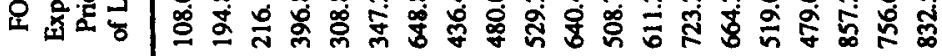




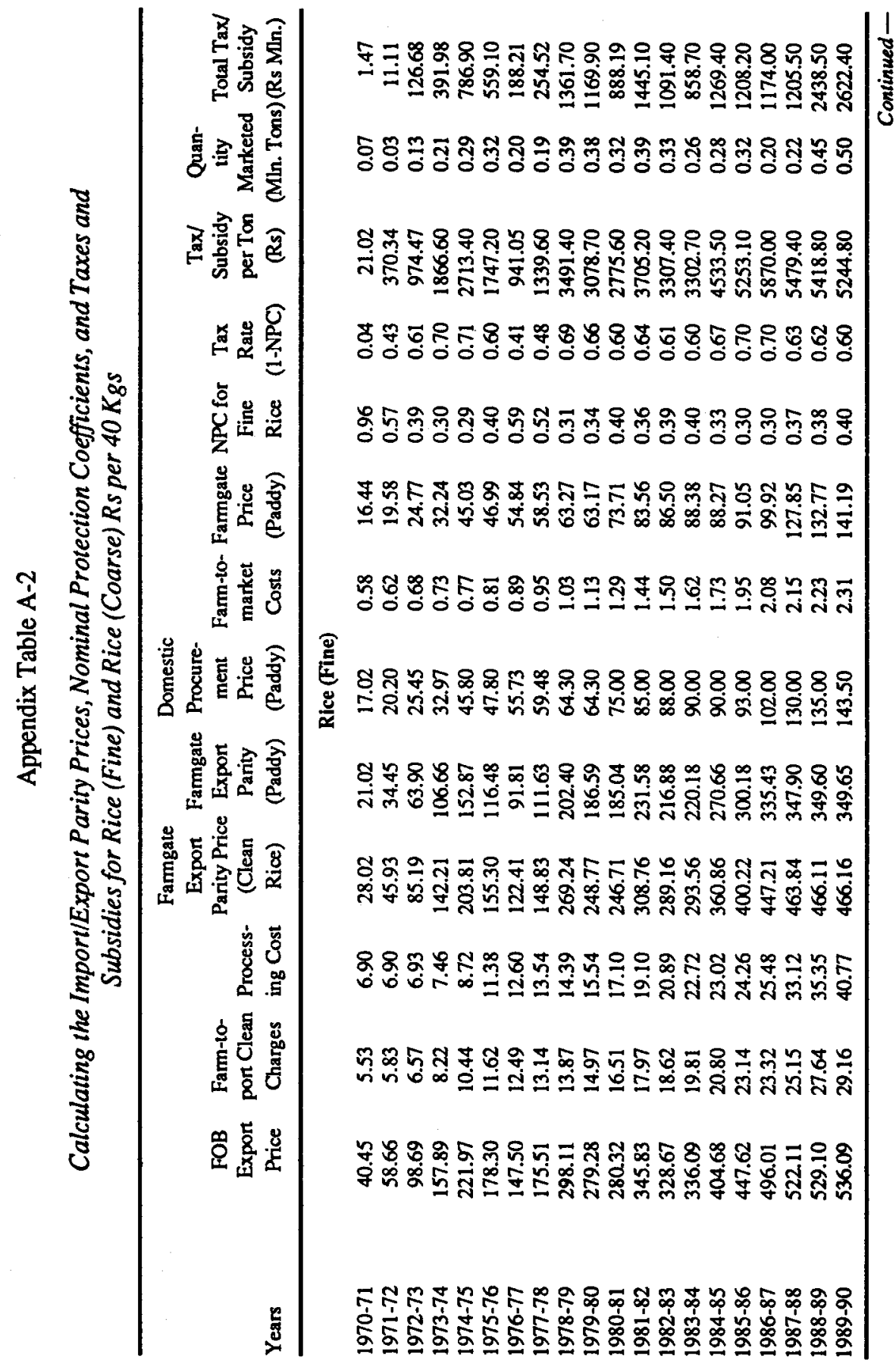




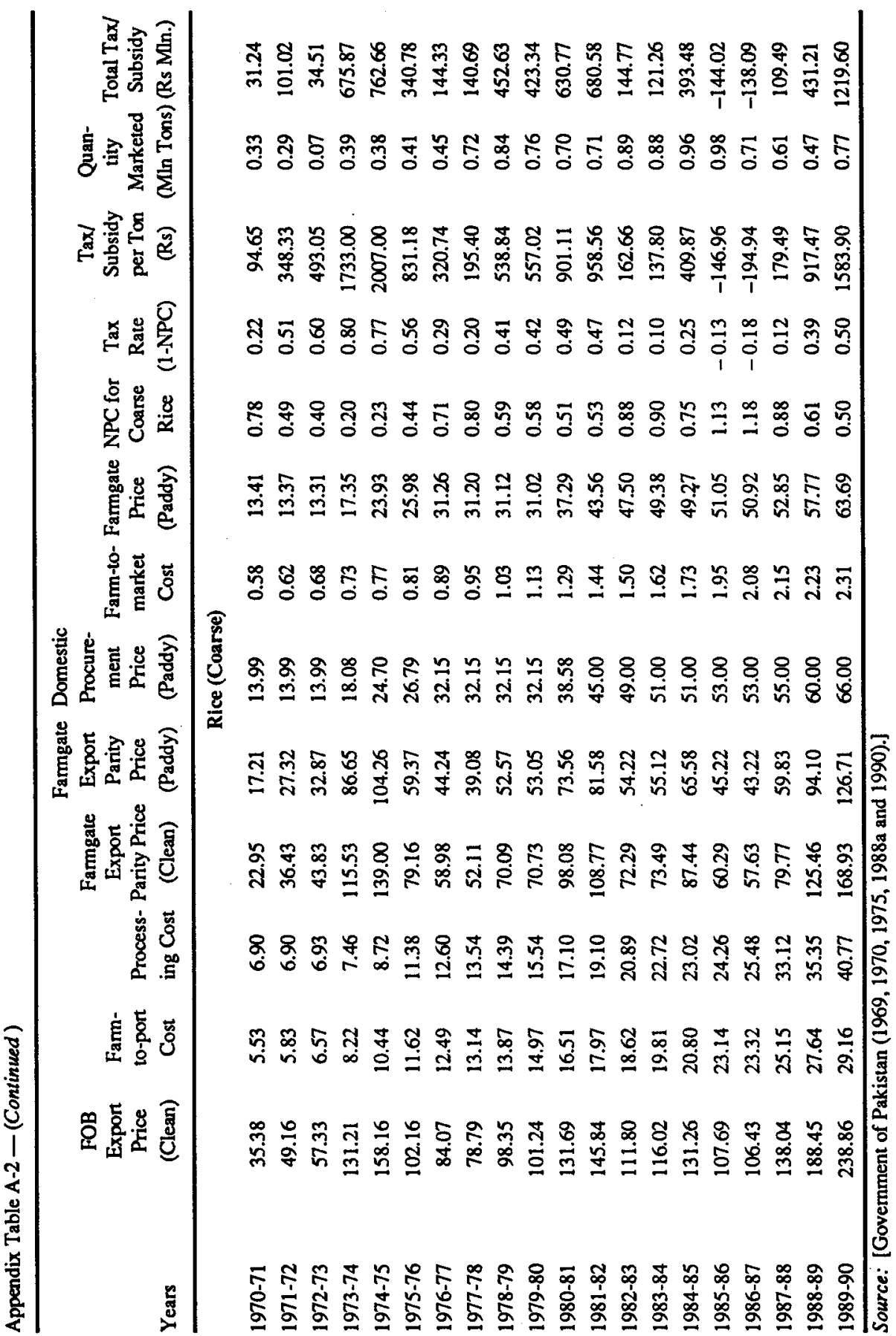




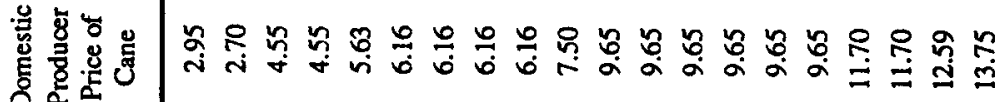

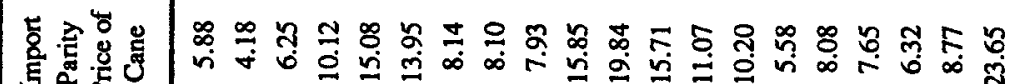

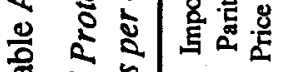

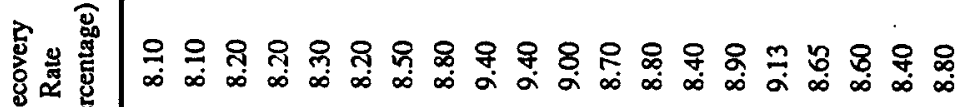

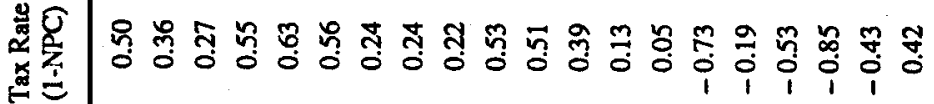

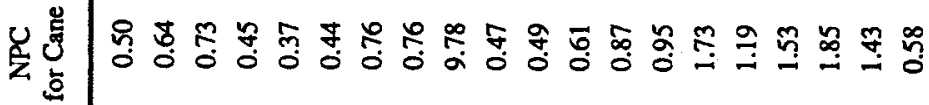

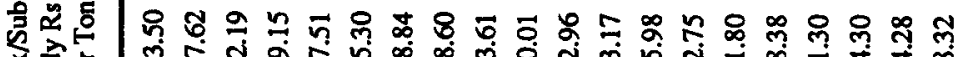

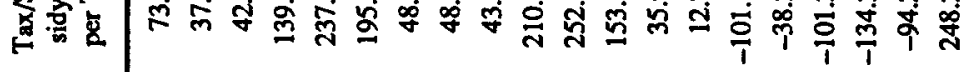

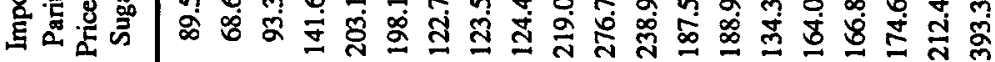

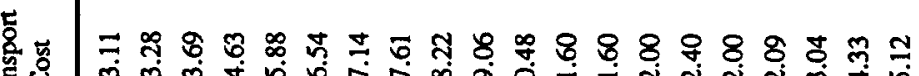

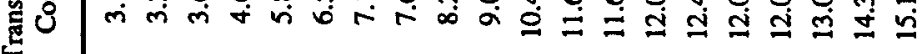
to.

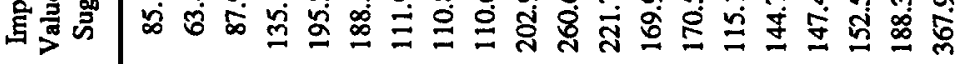




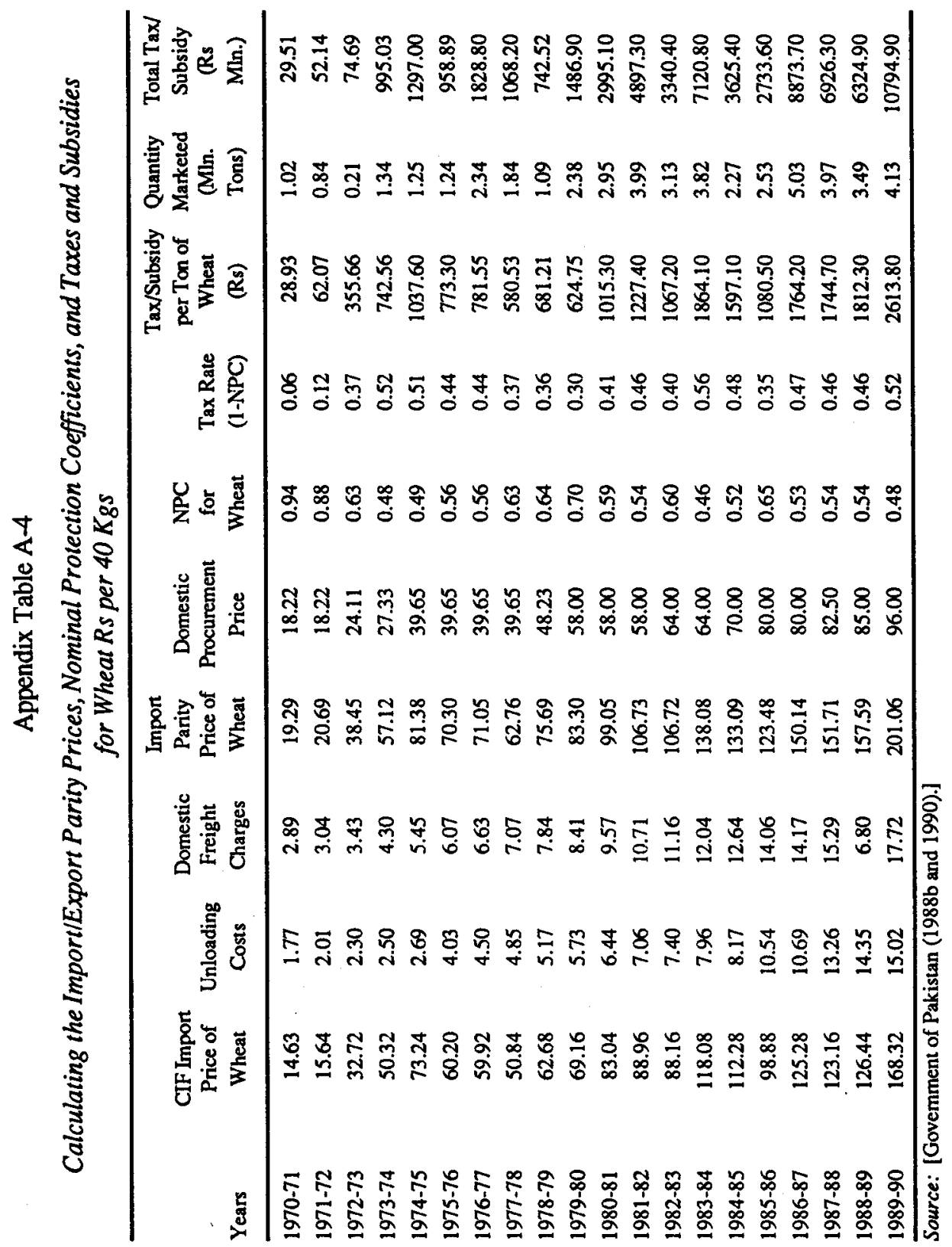




\section{REFERENCES}

Ali, Mubarik (1990) Price Response of Major Crops in Pakistan: An Application of the Simultaneous Equation Model. The Pakistan Development Review 29 : 3-4 305-325.

Appleyard, Dannis R. (1987) Report on Comparative Advantage. Islamabad: Agricultural Prices Commission. (APCOM Series No. 61.)

Bale, Malcolm D. (1985) Agricultural Trade and Food Policy: The Experience of Five Developing Countries. Washington, D. C.: The World Bank. (World Bank Staff Working Paper No. 724.)

Chaudhry, M. Ghaffar (1973) The Problem of Agricultural Taxation in West Pakistan and an Alternative Solution. The Pakistan Development Review 12 : 2 93-122.

Economic Commission for Asia and the Far-East (1966) Tax Potential and Economic Growth in the Countries of the ECAFE Region. Economic Bulletin for Asia and the Far-East 45 Scplember.

Ender, Gary (1989) Producer and Consumer Subsidy Equivalents for Important Crops and Livestock Products in Pakistan: Report of Work Completed for USAID. Islamabad: USAID.

Gotsch, Carl H., and Gilbert T. Brown (1980) Prices, Taxes and Subsidies in Pakistan's Agriculture: 1960-76. Washington, D. C.: The World Bank. (World Bank Staff Working Paper No. 387.)

Hamid, J. (1970) Suggested Approach to Agricultural Taxation Policy in West Pakistan. The Pakistan Development Review $10: 4 \quad 422-447$.

Khan, Mahmood Hasan (1985) Agrarian Transformation in Pakistan. Islamabad:

Pakistan Institute of Development Economics. (Lectures in Development Economics, No. 4.)

Krueger, Anne O. et al. (1988) Agricultural Incentives in Developing Countries: Measuring the Effects of Sectoral and Economy-wide Policies. World Bank Economic Review $2: 3$ 255-272.

Pakistan, Government of (1969) Year Book of Agricultural Statistics 1968. Islamabad: Ministry of Agriculture and Works; Food and Agriculture Division. Pakistan, Government of (1970) Year Book of Agricultural Statistics 1969. Islamabad: Ministry of Agriculture and Works; Food and Agriculture Division. Pakistan, Government of (1975) Agricultural Statistics of Pakistan 1975. Islamabad: Ministry of Food, Agriculture and Co-operatives; Agriculture Wing (Planning Unit).

Pakistan, Government of (1986) National Taxation Reforms Commission: Final Report. Islamabad: Ministry of Finance; Finance Division.

Pakistan, Government of (1987) Markets and Prices, Annual Bulletin 1986-87. 
(Vol. 38, No. 12-A). Karachi: Agricultural and Livestock Marketing Adviser. Pakistan, Government of (1988) Agricultural Statistics of Pakistan 1986. (Vol. I). Islamabad: Ministry of Food, Agriculture and Co-operatives; Food and Agriculture Division (Planning Unit).

Pakistan, Government of (1988a) Economic Survey 1987-88. Islamabad: Economic Adviser's Wing; Finance Division.

Pakistan, Government of (1988b) Report of the National Commission on Agriculture. Islamabad: Ministry of Food, Agriculture and Co-operatives. Pakistan, Government of (1989) Agricultural Statistics of Pakistan 1988-89. Islamabad: Ministry of Food, Agriculture and Co-operatives; Food and Agriculture Division (Planning Unit).

Pakistan, Government of (1989a) Foreign Trade Statistics of Pakistan, Imports April-June 1989. (Part II, Vol. 24, No. 4, and No. 4 of various volumes from 1971 and 1988). Islamabad: Federal Bureau of Statistics; Statistics Division.

Pakistan, Government of (1989b) Markets and Prices. (Monthly Bulletin). (December 1989, Vol. VIII. No. 5.) Karachi: Agricultural and Livestock Marketing Adviser.

Pakistan, Government of (1990) Economic Survey 1989-90. Islamabad: Economic Adviser's Wing; Finance Division.

Qureshi, Sarfraz K. (1987) Agricultural Pricing and Taxation in Pakistan. Islamabad: Pakistan Institute of Development Economics.

Scandizzo, Pasquale L., and Colin Bruce (1990) Methodologies for Measuring Agricultural Price Intervention Effects. Washington, D. C.: World Bank. (World Bank Staff Working Paper No. 394.)

Wainio, John et al. (1988) Methodology: PSEs as Aggregate Measure of Support. In Agriculture in the Uruguay Round: Analysis of Government Support. Washington, D. C.: USDAERS. (Staff Report 880802.) 